\title{
The Aesthetics Effect of Surakarta-Style Pakeliran on East Javanese Pakeliran
}

\author{
$\bowtie$ Sugeng Nugroho
}

Faculty of Performing Arts, Institut Seni Indonesia Surakarta, Indonesia

Received: October 18, 2017. Revised: August 14, 2018. Accepted: December 6, 2018

\begin{abstract}
This study intends to explore the aesthetics of East Javanese Shadow Puppet (Wayang Kulit Jawa Timuran) show as one of the people's style puppet show model. The problems discussed are related to how East Javanese Shadow Puppeteers respond to the existence of The Surakartastyle shadow puppet shows that are not only flourished in the Central Java region but also in most parts of East Java. This study uses qualitative methods with descriptive analytical analysis. Research data are collected through literature studies, documentation studies, interviews, and field observations. The results of the study show that East Javanese shadow puppet show, both performance elements, the structure, and some elements of "garap pakeliran" have currently been colored by the idioms of Surakarta-style shadow puppet show.
\end{abstract}

Keywords: Aesthetics; Shadow Puppet Show; Surakarta Style; East Javanese Style

How to Cite: Nugroho, S. (2018). The Aesthetics Effect of Surakarta-Style Pakeliran on East Javanese Pakeliran. Harmonia: Journal of Arts Research And Education, 18(2), 153-161.

\section{INTRODUCTION}

East Javanese-style shadow puppet show (hereinafter referred to as Pakeliran Jawa Timuran), or better known as 'wayang jekdong' or 'wayang dakdong', is a form of shadow puppet show that grows and develops in the brangwétan region, which is across the east of the watershed Brantas. This pakeliran has a relatively narrow of performing range when compared to the area of East Java Province which consists of 29 regencies and 9 cities. Pakeliran Jawa Timuran only lives in villages in Jombang Regency, Mojokerto, Malang, Pasuruan, Sidoarjo, Gresik, Lamongan, and on the outskirts of Surabaya.

Pakeliran Jawa Timuran, both the aspects of the wayang artistry, the structure of the play, and the style of the per- formance are very different from those of Sura- karta and Yogyakarta styles. Based on the style of the show, Pakeliran Jawa Timuran can be grouped into four sub-styles, name- ly: (1) Sub-style Lamongan (with the mas- termind Ki Subroto), lives and develops in the Lamongan area and its surroundings; (2) Sub-style Mojokertoan (with the master- mind Ki Piet Asmoro), lives and develops in the area of Jombang, Mojokerto, and its surroundings; (3) Sub-style Porongan (with the mastermind Ki Soleman), lives and de- velops in the Sidoarjo area, Surabaya, and its surroundings; and (4) Sub-style Malang- an (with mastermind figures, Ki Abdul Mukid, Ki Matadi, and Ki Wuryan We- dharcarita), lives and develops in Malang and surrounding areas. Even from other Jawa Timuran sub-styles, this Pakeliran Ma- langan has a different

\footnotetext{
${ }^{\triangle}$ Corresponding author: Jl. Ki Hajar Dewantara No.19, Jebres, Kota Surakarta, Jawa Tengah 57126

E-mail: sgngnugroho@gmail.com
} 
style of performance (Timoer, 1988, p. 19). The differences in performance patterns in each region occur because each region has its own referen- ce to puppetry which is formed from the individual styles of each puppeteer and inherited from generation to generation. Pakeliran Jawa Timuran has a more simp-le, straightforward, familiar, and flowing aesthetics (Javanese: gayeng, gobyog, rame). The nuances of puppet art show which is gayeng, gobyog, ramé are strongly influen- ced by the nuances of togetherness and intimacy of rural and/or coastal commu- nities (pesisiran) (Kayam, 1981; 2001).

Based on the field study, it was found that not all East Javanese puppeteers presented Pakeliran Jawa Timuran, because not all East Javanese people liked Pakeliran Jawa Timuran. Some communities in certain areas such as Magetan, Ngawi, Madiun, Nganjuk, Pacitan, Ponorogo, Trenggalek, Tulungagung, and Blitar, prefer Surakarta-style pakeliran, so that the puppeteers who live in the area mostly adhere to the Surakarta-style of Pakeliran. Why did this happen in the life of puppetry in East Java?

Research on the aesthetics influence of the Surakarta-style pakeliran on Pakeliran Jawa Timuran is urgent to be done, considering that until now there has been no scientific study to discuss it. The two previous writings, the Wayang Malangan, written by Suyanto (2002), emphasizes more on the origins and life of Malangan sub-style shadow puppets; while "Nyalap Nyaur: The Management Model of Jekdong Puppet Performance in the Celebration of East Javanese Traditions," Wisma Nugraha Christianto writing focuses on the management model of the East Javanese puppeteers both during quiet and crowded stage performances (Rich, 2012). Meanwhile, the article entitled "Artistic and Aesthetic Concepts of Javanese Puppetry Art," written by Nugroho (2007), only discusses the differences in artistic concepts and aesthetic concepts of Javanese puppetry in general. "Rasa: Affect and Intuition in Javanese Musical Aesthetics", Benamou's writing (2010) focuses more attention on the issue of the feeling underlying the aesthetics of traditional Javanese music. "The Concept of Taste in Purwa Wayang Kulit Show," written by Sunardi (2012), only reveals indicators of rasa regu, greget, sedhih, and prenès in a puppet show. Likewise "Estetika Wayang," Hadiprayitno (2014) writing, focuses more on the aesthetic basics in wayang kulit purwa shows.

Based on the background problems above, the problems of this research are: How did the East Javanese puppeteers react to it? That is, does the aesthetics of the Surakarta-style Pakeliran also affect $\mathrm{Pa}$ keliran Jawa Timuran? If the answer is 'yes', why did it happen? In accordance with the formulation of the problem set, this study aims to explore the aesthetics influence of the Surakarta-style Pakeliran on Pakeliran Jawa Timuran as a form of a popular style puppet show.

\section{METHODS}

This study uses qualitative methods with descriptive analytical analysis. The research data were collected through literature studies, documentation studies, interviews, and field observations related to the East Javanese shadow puppet show. The literature study was focused on books and manuscripts about East Javanese puppet show. The documentation study prioritizes several audio-visual recordings of $\mathrm{Pa}$ keliran Jawa Timuran. Interviews were conducted with puppeteers and East Javanese shadow puppet observers. The field observations focused on Pakeliran Jawa Timuran Sub-style Porongan, with the mastermind Ki Wardono (Mojokerto); Sub-style Mojokertoan, with mastermind Ki Pitoyo (Mojokerto); and Sub-style Malangan, with mastermind Ki Suyanto (Malang).

\section{RESULTS AND DISCUSSION}

\section{Performance Devices}

The stage of Pakeliran Jawa Timuran basically does not have a significant difference with the Surakarta-style pakeliran stage. The difference is because before the pakeliran takes place, it is started with the 
Ngréma dance performance, then there is usually an additional stage located in front of the shadow puppet stage. This additio- nal stage is also be used for the Ngréma dance performance arena, this stage is also sometimes used for the presentation of campursari music before the Ngréma dance takes place. There is an additional stage that blends with the shadow puppet stage, located behind the seats of the panjak (Central Java: pengrawit or niyaga), there are some that are set apart from the shadow puppet stage; depending on the conditions of the venue.

The gamelan used to accompany $\mathrm{Pa}$ keliran Jawa Timuran, especially sub-style Lamongan, Mojokertoan, and Lamongan before the 1970s, only had sléndro verses with 15 instruments: gendèr penerus, gendèr babok, rebab, kendhang, slenthem, gambang, panembung, bonang babok, bonang penerus, demung, saron I, saron II, peking, kenong, kempul and gong. The sléndro gamelan and pélog at that time were only used in Pake- liran Jawa Timuran sub-style Malangan. However, in its development, all sub-style pakeliran Jawa Timuran have used the sléndro-pélog instrument, which consists of: gendèr penerus, gendèr babok, rebab, kendhang wayangan, ketipung, kendhang ageng, slen- them, gambang, panembung, bonang babok, bonang penerus, demung I, demung II, saron I, saron II, peking, kenong, kempul and gong. Even with drums, cymbals, organs and guitars.

The musical instruments of gamelan wayangan like the last one called are 'new traditions' that developed in Javanese shadow puppet show, both in Surakarta, Yogyakarta and also in East Javanese today. It was called a 'new tradition' because the arrangement only appeared in the 1990s, which was started by pantap style pakeliran, namely a puppet show held in the courtyard of the Central Java Governor's Office by the Committee of Permanent Appreciation and Puppetry Art Development on the initiative of Soedjadi, Chair of Ganasidi (Indonesian Puppet Art Development Agency) in Central Java. The use of drums and cymbals is for stabilizing sound effects when puppets fight, while the use of or- gans and guitars is to accompany campursari songs.

Pakeliran Jawa Timuran has a charac- teristic in sampiran arrangement (the term East Javanese Puppetry) or simpingan (the term Central Javanese puppetry), which means figures of puppets which are plug- ged in lined up on the right and left of the puppet show screen (Javanese: $k e-$ lir). Sam- piran kanan (from front to back) consists of Batara Kala, Batara Bayu, Werkudara, Bratasena Baladewa, Gathutkaca, Antareja, monkeys, deities, subtle kings, king's sons/ princes (Javanese: putran), Batara Guru (facing left with the position above the other sampiran puppets), puppet princess, and small puppet figures. Sampiran kiri (from front to back) consists of giant king figures (Javanese: danawa raton), Dasa-muka, Suyudana, Dursasana, Pragota, prime ministers (Javanese: patihan), round-eyed puppet figures (Javanese: plelengan), puppet figures whose mouths are open so that their teeth and fangs appear (Javanese: prèngèsan), Setyaki, Batari Durga (facing right with the position above the other attachment puppets), the small-sized Kurawa, king seberang who has a handsome face (Javanese: sabrang bagus), and small puppet figures. Before the shadow puppet show begins, in the middle of kelir (the screen) are embedded puppet figures Semar and Bagong - sometimes accompanied by Besut - which are closed or located outside the kayon figure or gunungan.

The arrangement of shadow puppet figures in Pakeliran Jawa Timuran is different from the arrangement in the Surakarta-style pakeliran. The figures of the Baladewa in Pakeliran Jawa Timuran are included in sampiran kanan, in the Surakarta-style pakeliran is on simpingan kiri. The figures of Batara Kala and the gods in Pakeliran Jawa Timuran are included in the right side, in the Surakarta-style pakeliran included in the puppet dhudhahan category, which is puppet figures arranged in kothak or on top of the kothak lid on the right side of the puppeteer. Likewise, the small figures of Dursasana, Pragota, patihan, and Kurawa in the Surakarta-style Pakeliran be included 
in the category of wayang dhudhahan. The figures of Semar and Bagong in Surakartastyle pakeliran have never been kept together in simping with the kayon figure in the middle of kelir; these two puppet figures are in the wayang dhudhahan category.

\section{Performance Structure}

Pakeliran Jawa Timuran has a different structure from the Surakarta-style pakelir an. In East Javanese tradition, before the pakeliran began, a special East Javanese dance was performed, which is Ngréma in two styles; women style and men sty-le. The Ngréma dance is a package from the shadow puppet show and is presented between 9:00 and 23:00, in addition to the opening performance or reception of guests, this performance as well as to invite shadow puppet show viewers. Besides dancing, Ngréma dancers also sang campursari songs. They also received saweran from the spectators who participated in the dance (Javanese: ngibing) on the stage. In certain performances that are mass celebrations, before the Ngréma dance is usually enlivened with dangdut or campursari music performances which are presented by the committee from outside the shadow puppet group. They usually perform between 19:30 and 21:00.

Pakeliran Jawa Timuran has a simpler structure compared to the pakeliran structure of the Surakarta style tradition. The first part consists of four scenes: (1) jejer (standing in line) in an empire (with nuances of melody pathet sepuluh followed by pathet wolu), a king is confronted by the ministers, then the arrival of guests, and ending with all puppet figures leaving the place (Javanese: bedholan or budhalan); (2) pasé$b a n$, the prime minister ordered his troops to go to a place, ending with budhalan; (3) sepisan war, war between the royal forces jejer I against troops from other kingdoms; (4) jejer II in an empire, accepts the arrival of guests, ends with budhalan. The second part with the pathet sanga nuances, consists of three scenes: (1) jejer III in the hermitage (the priest is confronted by knights with panakawan: Semar, Bagong, and Besut) or in the middle of the forest (knight confronted by panakawan: Semar, Bagong, and Besut), continued by budhalan; (2) perang gagal or perang bégal, knight figures against giants which ends with the death of the giants; (3) jejer IV in a kingdom Jejer I, ending with budhalan. The third part with the nuances of melody pathet serang, consists of three scenes: (1) Jejer V in an accross kingdom, ending with budhalan; (2) Brubuh war, a war between figures in Jejer I against the figure on Jejer $\mathrm{V}$ which ends with the death of one party; (3) Jejer pamungkas (the final), the closing scene in a kingdom.

There are three things that distinguish between Pakeliran Jawa Timuran and Pakeliran Surakarta style. First, Pakeliran Jawa Timuran has four pathet areas (a system that regulates the role, position, and tone area of Javanese gamelan), namely pathet sepuluh, pathet wolu, pathet sanga, and pathet serang; whereas Pakeliran Surakarta style only has three pathet regions, namely pathet nem, pathet sanga, and pathet many- ura. Second, all scenes (except paséban and war) in Pakeliran Jawa Timuran are called jejer; whereas in Surakarta style the term jejer is only used to refer to the first scene, for the following scenes are called scenes or candhakan. It is called a scene when ac- companied by a certain composition and accompanied by a narration of the puppe- teer, and is called candhakan if it is only accompanied by melody at the level of ayak-ayak, srepeg, or sampak and is not accompanied by the narration of the puppeteers. Third, in Pakeliran Jawa Timuran, there are no kedhatonan scenes - which end in limbukan - and gara-gara scenes. Kedhatonan scene is a scene that depicts a king's empress accepting the presence of the king from the courtroom, while gara-gara scene is a scene that shows panakawan (Gareng, Petruk, and Bagong) joking and singing hymns. The joking of the Panakawan Jawa Timuran (Semar, Bagong, and Besut) are displayed in jejer III when they follow the knight who became their master.

The first and second cases up to now are still preserved as typical characteristics of Pakeliran Jawa Timuran, but for the thir- 
case at this time it has begun to wear off. That is, at this time Pakeliran Jawa Timuran also displays limbukan and gara-gara as well as Pakeliran Surakarta style now in general. Limbukan's appearance in Pakeliran Jawa Timuran, refers to the 1990s-style limbukan Surakarta style pakeliran, which appears as a 'loose scene' without beginning with kedhatonan scene. Likewise, gara-gara in Pakeliran Jawa Timuran refers to the Surakarta style of the Nartasabda era (the 1970s) pakeliran which was adopted from the Yogyakarta style pakeliran. The two scenes are used by the East Javanese puppeteers to convey social messages as well as to present campursari songs both at the choice of the puppeteer or the audience's request.

\section{Elements of Garap Pakeliran}

Garap pakeliran includes all elements of pakeliran expression, which consist of: catur, sabet, gending, sulukan, dhodhogan, and keprakan. Catur is the puppeter discourse presented in pakeliran. Sabet is everything related to the wayang movements in pakeliran. Gending is gamelan music which serves to accompany the nuances of giving wayang performances. Sulukan is a combination of poetry and songs performed by puppeteer to build a certain atmosphere in the pakeliran. Dhodhogan is the sound of a wooden beater (called cempala) which is struck on the inside or outside of the puppet box to build a certain atmosphere in the pakeliran. Keprakan is the sound of a number of metal plates (called keprak) which hang on the lip of the puppet box to build a certain atmosphere in pakeliran (Nugroho, 2012). Of the six elements of garap pakeliran, there is one element of garap that has similarities between Surakarta style pakeliran and Pakeliran Jawa Timuran, which is on garap catur, while the other garap elements (sabet, gending, sulukan, dhodhogan, and keprakan) shows typical East Java.

Catur in Pakeliran Jawa Timuran, based on the form of speech and its functions can be grouped into three types, namely janturan, pocapan, and ginem. Janturan is a narrative of puppeter to describe a scene that is presented along with the strains of melody that sound soft (Javanese: sirep). Pocapan is the puppeter's narrative to describe the events that have occurred and will occur in pakeliran which are presented without strains of melody; if using the strains of gending sounds soft it is called pocapan gadhingan. Ginem is a dialogue or monologue of puppet characters in pakeliran (Timoer, 1988). The naming of terms in this catur grouping can be ascertained to come from the term Surakarta style puppetry, except pocapan gadhingan. For Surakarta style puppetry, all the narratives of the puppeteers are presented in accompaniment of the sirep gendhing, both to describe a scene and events that have occurred and will occur in pakeliran, called janturan.

Janturan jejer 1 in the Pakeliran Jawa Timuran - although with different dialects and language styles - has the same sentence pattern and structure as janturan jejer on Surakarta style pakeliran tradition, consisting of: opening, royal names, geography, economic conditions, conditions of peace and state security, the loyalty of the courtiers, the name of the king along with its meaning and character.

The opening text of jejer I speech written as follows: "Yanenggih, sirepé data pitana sekaring panguneng-uneng, tiyang ngringgit ing sedalu menika nggelar carita jaman purwa." (This is a silence, a man masterminds the puppet show this night-long holding stories of the beginning.) This text bears similarities with the opening text of the lacerations in the Surakarta-style pakeliran which reads: "Swuh rep data pitana" (Nojowirongko, 1960, p. 70).

The janturan text that refers to the royal name in jejer I written as follows:

"Ingkang kanggé bebukaning carita anyariyosaken gelaring Nagari Darawa-ti. Wah éka adi dasa purwa madya wasana. Wah pengaraning wadhah, éka mring sawiji, adi linuwih, dasa sepuluh, purwa wiwitan, madya tengah, wasana wekasani kandha carita ing sadalu menika." (As the beginning of the story is told the condition of Dwa-rawati Country. Wah éka adi dasa purwa madya wasana. Wah means container, éka means one, adi means beautiful, dasa (ten), 
purwa (beginning), madya (middle), wasana (the end of the story tonight.)

This is similar to Surakarta style Janturan jejer text which is written as follows: "Anenggih pundi ta ingkang kaéka adi dasa purwa. Éka sawiji, adi luwih, dasa sapuluh, purwa wiwitan" (Nojowirongko, 1960, p. 70).

Janturan text that illustrates the geography of a state is written as follows: "...negari ngungkuraken gunung, ngayunaken lelayaran utawi samodra, ngéringaken pesabinan, nengenaken bengawan, mengku bandaran agung." (... a country back to the mountain, facing the ocean, on its left is agricultural land, on the right is a large river, has a lar- ge port.) This is the same as janturan text in the Surakarta style written as follows: “... nagari ngungkuraké pagunungan, ngéring- aké pasabinan, nengenaken benawi, ngayunken bandaran gedhé" (Nojowirongko, 1960). The text created by Padhasuka (Pasinaon Dha-lang ing Surakarta) in around 1923 actually depicts the geographical location of the Surakarta Palace, which is back to the mountain (Pegunungan Seribu), on the left (west) of agricultural land (Boyolali and Klaten), next to the right (east) has a Bengawan Solo stream, and in front of it in distance there is a port (Tanjung Emas, Se- marang). Because Janturan jejer text is stan- dardized as a reference for Surakarta style puppetry, the PDMN (Pasinaon Dhalang ing Mangkunegaran) also uses the same pattern, even though the Mangkunegaran Palace faces south.

Janturan text that illustrates the economic condition of a country is written as follows:

"...tiyang dagang layar, botena para priyantun, senajan tiyang alit ingkang ahli nyambut damel kulak cantak wlijo bakul, adola godhong adola biting do- dola suket utawi mubeng pasar tanpa bandha pisan padha seneng ati, cukup sing disandhang lan sing pangan, datan ana sing kacingkrangan uripé. Menapa déné tiyang manca negari ingkang andon bebara nyambut damel ngantos jejel, tanah jembar ketingal rupek ananging andadosaken raharjané negari. Tiyang alit ingkang narakisma panggaraping bumi lampahé pertanian samya mungkul pangolahing tetanem, samya tulus ingkang sarwa tinandur...."

(... traders and sailors, not only the upper classes, even ordinary people who like working as broker and traders, leaf sellers, palm leaf ribs sellers, grass sellers or those who just go around the market without any capital are happy, fulfilled clothing and food, there is no miserable life. Even foreigners who make a fortune to work as workers are so plenty, so the land becomes narrow but it adds to the excitement the country, the farmers are diligent in working on agricultural land, the plants grow well ....).

This text is similar to Janturan jejer in the Surakarta style text, which is written as follows:

“... gemah kang lumaku dagang, rainten dalu tan ana pedhoté, labet tan ana sangsayaning margi. Aripah janma ing manca kang sami griya salebeting praja jejel apipit, pangrasa aben cukit tepung taritis, papan wiyar $k a-$ tingal rupak saking rejaning nagari. Karta kawula ing padhusunan padha tentrem atiné, mungkul pangulahing tetanèn ...." (Nojowirongko, 1960, p. 70).

(... gemah means the course of day and night trade is endless, because there is no security disturbance. Aripah means foreigners who are domiciled in the kingdom are seem crowded, their houses huddled together, wide boards appear narrow because of the hectic situation. Karta means people in the countryside feel secure, diligently working on agriculture ...)

The text describing the state of peace and security of a country is written as follows:

"Panguripané kawula ayem tentrem kadayan saka amané negara, lampahé durjana utawa maling brandhal kampak kècu datan ana, mila ingon-ingoné kawula alit rupia sato iwèn bèbèk ayam datan ana kang dèn-kandhangi, senadyan rupia rajakaya maèsi lembu kuda ménda datan ana cinancangan, yèn ènjing dèn-umbar ana pangonan abyoor 
kadya jambé jebug sinawuraken. Montro wétan ngendanu kilèn wancinira jam sekawan setengah gangsal sonten rajakaya dèn-giring dhateng kandhan- gipun piyambak-piyambak ...."

(People's life is peaceful because of its guaranteed security; no thieves, hoodlums, robbers, so that pets like ducks and chickens need not to be kept in cages: buffaloes, cows, horses, goats need not to be tied up, when the morning comes, they look for food $b$ themselves, in the afternoon at four, half past four the livestocks are herded into each of their cages ...).

This is similar to the Surakarta style janturan jejer text, which is written as follows: "... ingon-ingon kebo sapi pitik iwèn tan ana cinancangan, rahina aglar ing pangonan, yèn bengi mulih marang kandhangé dhéwé" (Nojowirongko, 1960, pp. 70-71 ) (... buffaloes, cows, chickens, ducks are not tied, during the day they are left in the field, at night they return to each of their cages.)

The text describing the loyalty of the royal court officials is written as follows: "Senadyan lampahé nayakaning praja dalah sak-panekaré dalah para mantri-mantri bupati samya bekti dhateng kuwajibané sumungkem ing negara njunjung dhateng kaluhuraning Sang Nata!" (Royal court officials and their staff and the regent mantry work diligently faithful to the state, devoted to the king.) This text is similar to the Surakarta style janturan jejer text, which is written as follows:

"Raharja tebih ing parangmuka, déné para mantri bupati padha kontap kautamané, bijaksana limpad ing kawruh putus marang wajib pangrèhing praja, tansah hambudi wewahé kaluhuraning nata" (Nojowirongko, 1960, p. 71).

(Raharja far from the attack of the enemy, while the regents seem loyal, wise, clever, able to carry out their obligations, always trying to improve the noble- ness of the king.)

The text that depicts the name of the king and its meanings and characters is written as follows: "... jejuluk Sang Maha Prabu Bathara Kresna, ya Sang Prabu Padmanaba, ya Prabu Harimurti, ya Prabu Danardana, Radèn Narayana jeneng klairané. Jejuluk Bathara Kresna, tegesé Kres = tajem utawa landhep, na = wujud utawa ning, bathara = déwa, ratu gung binathara sinebut déwa kamanungsan, wujudé ireng cemani nanging cukup kawuningané landhep panggraitané... seneng paring pepadhang wong kepeten- gan, paring kudhung wong kepanasan, awèh payung wong kodanan, awèh sandhang wong kawudan, paring pangan wong kasatan."

(... titled Sang Maha Prabu Batara Kresna, Prabu Padmanaba, Prabu Harimurti, Prabu Danardana, Raden Narayana in- born name. Batara Kresna, meaning Kres $=$ sharp, $n a=$ manifested, bathara $=$ deity, king which is alike god or deity in a hu- man body form, has a black and smooth but very knowledgeable and intelligent... likes to enlighten darkness, gives a hat to someone who is hot, gives an umbrel- la to people who get wet in rain, gives clothes to people who do not have clot- hes, feeds to those who are starving.)

This text is similar to the Surakarta style janturan jejer text, which is written as follows:

“... Sri Bathara Kresna, Prabu Arimurti, Padmanaba, Narayana, Késazwa, Wasudézwa, Wisnumurti, Danardana, Janardana. Mila je- juluk Sri Bathara Kresna, cemeng pasarirané trus balung sungsum ludirané, yèn ayama ayam cemani, keni kinarya sarana, sanadyan Sri Kresna uga dadya sarana jayaning Pand- hawa ing Bratayuda ... paring sandhang wong kawudan, asung pangan wong kaluwèn, awèh banyu wong kasatan, paring teken wong kalu- nyon, asung kudhung wong kepanasan, awèh payung wong kodanan, karya sukaning priha- tin, amaluyakaken wong asakit" Nojowirongko, 1960, p. 71).

(... Sri Batara Kresna, Prabu Arimur- ti, Padmanaba, Narayana, Kesawa, Wasudewa, Wisnumurti, Danardana, Janardana. Titled Sri Batara Kresna, his skin is black to bone marrow and blood; if 
chicken is a smooth black chicken, can be used as a tool, so too Sri Krishna can be used as a means of glory of the Pandavas in Bratayuda ... giving clothes to people who do not have clothes, feeding people who are starving, giving water to people affected by drought, giving sticks to people who walk on slippery roads, giving hats to people who are overheating, giving umbrellas to people who are in the rain, entertaining people who are difficult, treating sick people.)

Catur in Pakeliran Jawa Timuran has a type of pocapan which functions to describe the figure, clothing, and the magical power; to describe the shape of a vehicle (such as a train, horse, elephant) and its magic; to describe the form of a weapon (such as an arrow) and its magic; or describe other things (like fire, water, wind) and their strength. This type of pocapan is called the term suwaka, which in the Surakarta style of pakeliran is called pocapan pamijèn. Although speaking with dialects and typical East Javanese language styles, the pocapan structure is similar to the Surakarta style pocapan pamijèn structure.

The ginem jejer structure in Pakeli- ran Jawa Timuran has similarities with the ginem jejer structure and scenes in the Surakarta style pakeliran, which consists of ginem blangkon followed by ginem baku. Ginem blangkon is a cliche dialogue that contains welcome from the host to the party that comes to face, or contains a report of a royal court official to the king about the situation and condition of the country. The ginem baku is a conversation between groups related to certain problems discussed in a trial or meeting. The similarity the Ginem type also occur in dialects and idiolects of puppet figures, for example: (1) the word ulun or jenengulun which is used to refer to ' $\mathrm{I}$ ' for deities when dealing with servants; (2) the word jenengkita that is used to refer to 'you' for the god character to his servant; (3) the word Adhi Guru is used by Narada to call to Batara Guru; (4) the word Yayi Samiaji used by Kresna to call to Puntadewa; (5) a call Jlitheng Kakangku used by Bima to call upon Kresna;
(6) a call Jlamprong adhiku used by Bima to summon Arjuna; (7) the word bojlengbojlèng con-demned devil is used as an style of giants.

Related to when Surakarta style $p a-$ keliran began to influence Pakeliran Jawa Timuran, indeed it cannot be stated withcertainty. Nevertheless, there is one clue, that since the Surakarta Kasunanan Karaton established dalang (puppeteer) schoolsnamed Padhasuka (1923) and Mangkunegaran founded dalang schools named PDMN (1931), many puppeteers from outside Surakarta even outside Central Java who had been selling well in their regions Duyun attended puppeteer education in one of these places. That pakeliran style of Padhasuka and PDMN became known as the Surakarta style pakeliran. They participated in puppeteer education in Padhasuka or PDMN in addition to increasing the puppetry's intellectuality, as well as to increase prestige among the public observing puppets (Van Groenendael, 1987, pp. 5362). It is possible since that time the texts of the Pakeliran Jawa Timuran discourse were contaminated by Surakarta-style pakelirandiscourse texts presented by puppeter graduates of Padhasuka or PDMN.

The change in the artistic orientation of the East Javanese puppeteers was increasingly apparent when the reality showed that the puppeters who had popularity above the other average puppeters were the Surakarta-style pakeliran. A number of the names of puppeters are popular in Central Java, where they refer to Surakarta style puppetry namely Pujasumarta (Klaten), Nartasabda (Semarang), Anom Soeroto (Surakarta), Manteb Soedharsono (Karanganyar), Purbo Asmoro (Surakarta), and Enthus Susmana (Tegal). Even some East Javanese puppeteers whohave popularity above the average of other puppeters, such as Panut Sasra Dharmaka (Nganjuk), Harjunadi (Nganjuk), Sakri (Madiun), Hari Bawana (Lumajang), andSun Gondrong (Tulungagung) have Surakarta style shadow puppet show. This means that the existence of the Surakarta style pakeliran has a very strong influence not 
only in the Central Java region but also in most of East Java.

\section{CONCLUSION}

Based on the description above, it can be concluded that wayang kulit as a work of art, both art and performing arts, is not a'dead' tradition, but a tradition of 'living'. This type of art always changes and develops according to the context. Likewise, Pakeliran Jawa Timuran which grows and develops as an oral tradition, always changes from time to time in accordance with the wishes of its people. Pakeliran Jawa Timuran as 'folk art' or 'small tradition' in life has become increasingly marginalized, pressured by the 'great tradition' which increasingly dominates the world of puppet shows, namely the Surakarta style of Pakeliran. Therefore, to maintain its existence, the Javanese puppeteers inevitably had to make a breakthrough by adopting several sets of performances, part of the structure of the scenes, and some elements of the Surakarta style of Pakeliran.

\section{REFERENCES}

Benamou, M. (2010). Rasa: Affect and Intuition in Javanese Musical Aesthetics. USA: Oxford University Press.

Bogdan, R. C. \& Biklen, S. K. (1982). Qualitative research for education: An introduction to theory and methods. USA: Allyn and Bacon.

Hadiprayitno, K. (2014). Estetika Wayang. Jurnal Budaya Nusantara, 1(1), 31-39.

Kartadirdjo, S. (1982). Pemikiran dan Perkembangan Historiografi Indonesia. Jakarta: PT. Gramedia.

Kayam, U. (1981). Seni, Tradisi, Masyarakat. Jakarta: Sinar Harapan.

Kayam, U. (2001). Kelir Tanpa Batas. Yogyakarta: Gama Media.
Miles, M. B. \& A.M. Huberman. (1984). Qualitative data analysis: A sourcebook of a new methods. Berverly Hills: Sage Publication.

Nojowirongko, M.Ng. (1960). Serat Tuntunan Pedalangan Tjaking Pakeliran Lampahan Irawan Rabi. Jogjakarta: Tjabang Bagian Bahasa Djawatan Kebudajaan Departemen P.P. dan K.

Nugroho, Sugeng. (2007). Konsep-konsep Artistik dan Estetik Seni Pedalangan Jawa. Dewaruci, Jurnal Pengkajian dan Penciptaan Seni, 4(3), 319-338.

Nugroho, S. (2012). Lakon Banjaran: Tabir dan Liku-likunya, Wayang Kulit Purwa Gaya Surakarta. Surakarta: ISI Press.

Pramono, S.A. (2004). Naskah Pakeliran Wayang Kulit Gagrag Malangan. Malang: Universitas Negeri Malang.

Rich, W.N.C. (2012). Nyalap-nyaur: Model Tatakelola Pergelaran Way- ang Jekdong dalam Hajatan Tradisi JawaTimuran. Humaniora, 24(2), 175-186. Retrived from https://jurnal.ugm.ac.id/jurnal-humaniora/ article/view/1060/889

Spradley, J.P. (1980). Participant Observation. New York: Holt, Rinehart and Winston.

Sunardi. (2012). Konsep Rasa dalam Pertunjukan Wayang Kulit Purwa. Jurnal Pendidikan dan Kebudayaan, 18(2), 192-203

Sunardi. (2013). Nuksma dan Mungguh Konsep Dasar Estetika Pertunjukan Wayang. Surakarta: ISI Press.

Surwedi. (2007). Layang Kandha Kelir. Jakarta: Balai Pustaka.

Suyanto. (2002). Wayang Malangan. Surakarta: Citra Etnika.

Timoer, S. (1988). Serat Wewaton Pedhalangan Jawi Wetan, Jilid I. Jakarta: Balai Pustaka.

Van Groenendael, V.M.C. (1987). Dalang Di Balik Wayang. Jakarta: Pustaka Utama Grafiti. 